\title{
Renal Processing of Albumin in Diabetes and Hypertension in Rats
}

Possible Role of TGF- $\beta 1$

\author{
Leileata M. Russo ${ }^{a}$ Tanya M. Osickab $^{b}$ Gail C. Brammar ${ }^{b}$ \\ Riccardo Candido $^{b}$ George J erums ${ }^{b}$ Wayne D. Compera \\ a Department of Biochemistry and Molecular Biology, Monash University, Clayton, Victoria, b Endocrine Unit \\ and Department of Medicine, University of Melbourne, Melbourne, Victoria, and Repatriation Medical Centre, \\ Heidelberg, Victoria, Australia
}

\section{Key Words}

Albuminuria - Hypertension - Streptozotocin - Lysosomal processing · Protein fragmentation - Glomerular permeability - Transforming growth factor- $\beta 1$. Peptiduria

\begin{abstract}
Background/Aims: Recent studies show that albuminuria may be the result of changes in post-glomerular cellular uptake and processing of albumin. This study aims to determine whether this processing is disrupted in diabetes and/or hypertension. Methods: Diabetes (d) was induced using streptozotocin in spontaneously hypertensive rats (SHR) and normotensive Wistar Kyoto rats (WKY) and studied after 8, 16 and 24 weeks of disease. Intact albumin excretion was determined by radioimmunoassay. Total albumin was determined by $\left[{ }^{14} \mathrm{C}\right]$ albumin . Lysosomal activity was determined by dextran sulfate desulfation. Renal TGF- $\beta 1$ and transforming growth factor- $\beta 1$ inducible gene-h3 mRNA ( $\beta$ ig-h3) expression was determined by real time RT-PCR. Results: SHR-c rats exhibited an increase in intact albuminuria without significant change in total albumin excretion (intact plus albumin-derived peptides). For WKY-d rats, intact albuminuria developed initially, followed by an increase in
\end{abstract}

total albumin excretion primarily in the form of albumin peptides (peptiduria). SHR-d rats exhibited both increases in peptiduria and intact albuminuria. There was no increase in glomerular permeability at 24 weeks for polydisperse $\left[{ }^{3} \mathrm{H}\right] \mathrm{Ficoll}$ in all groups. Increased renal TGF- $\beta 1$ and $\beta$ ig-h3 expression was correlated with a decrease in dextran sulfate desulfation and increased intact albuminuria independent of peptiduria. Conclusion: Increased albumin excretion in hypertension and/ or diabetes is manifested in different forms independent of glomerular permeability.

Copyright $\odot 2003$ S. Karger AG, Basel

Albuminuria, as determined by immunochemical assays, is one of the earliest clinical markers for diabetic nephropathy, and more recently a predictor of renal damage and cardiovascular disease in hypertension $[1,2]$. Recent studies have demonstrated that filtered albumin, like other filtered proteins, undergoes lysosomal-mediated fragmentation during renal passage [3] which results in filtered albumin being excreted predominantly in a fragmented form. Analysis of urinary albumin by immunochemical assays have been shown to detect intact albumin which represents only a small proportion of the total amount (intact plus albumin peptides) excreted [4, 5].

\section{KARGER}

Fax + 41613061234 E-Mail karger@karger.ch www. karger.com
(C) 2003 S. Karger AG, Basel

0250-8095/03/0232-0061\$19.50/0

Accessible online at:

www. karger.com/ajn
Wayne D. Comper

Department of Biochemistry and Molecular Biology

Monash University

Wellington Road, Clayton, Victoria 3800 (Australia)

Tel. +61 39905 3774, Fax +6139876 5851, E-Mail wayne.comper@med.monash.edu.au 
There is an urgent need, therefore, to understand the quantitative relationships by which filtered intact albumin and albumin peptides are excreted in diabetes and/or hypertension.

Recent findings have shown that albumin is filtered according to its size and is processed by two cellular pathways distal to the glomerular basement membrane (GBM). The majority of filtered albumin is retrieved and returned to the circulation, intact, via the 'retrieval pathway' $(>95 \%)$ [6]. The remaining $<5 \%$ is degraded in lysosomes, regurgitated back into the tubule lumen and excreted as degradation products via the "degradation pathway' [7-9]. Changes in albumin processing via the degradation pathway may directly affect intact albumin excretion without changing the total albumin excretion (intact plus albumin peptides). Disruptions to the retrieval pathway may lead to increases in total albumin excretion where albumin is excreted intact or as peptides due to degradation prior to excretion. The nature of these permutations in diabetes- and/or hypertension-related renal disease is unknown. They are likely, however, to be of major importance in characterising the manifestation of renal disease as it has been recently shown in glomerulonephritis that albuminuria can occur independently of changes in albumin permeability at the glomerular capillary wall (GCW) [10].

Although the causal events leading to albuminuria are unknown it is apparent that there may be a direct relationship between increased cytokine expression of TGF- $\beta$, and the onset of albuminuria. Analysis of TGF- $\beta$ isoforms in diabetes suggests that they are up-regulated [11] and this has been linked to increased glucose levels [12]. Upregulation of TGF- $\beta$ has also been demonstrated in stroke-prone spontaneously hypertensive rats [13] (possibly due to expression by mesangial cells associated with stretching forces [14-16] brought about by high intra-glomerular pressure). Although TGF- $\beta$ has long been noted for its fibrogenic potential $[12,17,18]$, recent studies suggest that TGF- $\beta$ also influences lysosomal enzyme activity [19]. This may provide an interesting new mechanism for how TGF- $\beta$ may be involved in the onset of albuminuria in both diabetes and in hypertension. Increases in the level of TGF- $\beta$ may alter lysosomal activity leading to disrupted albumin handling by the degradation pathway giving rise to increased excretion of intact albumin observed in these states. Although the measurement of TGF- $\beta$ is difficult, analysis of TGF- $\beta$ inducible gene-h3 ( $\beta$ ig-h3) mRNA expression allows one to analyse TGF- $\beta$ translation using polymerase chain reaction (PCR) [20].
This paper explores the effect that diabetes has on the origins of albuminuria in rats with and without hypertension as determined by changes in albumin permeability, total albumin and intact albumin excretion. Changes in lysosomal activity that could also influence albuminuria and the relationship between decreased lysosomal activity and altered renal TGF- $\beta 1$ expression is also analysed.

\section{Research Design and Methods}

\section{Experimental Animals}

Male SHR and WKY rats weighing 200-250 g were obtained from the Australian Resource Centre (Perth, Australia). Throughout the experimental period all rats were housed in rat boxes, under a 12-hour day/night cycle with free access to standard rat chow and water and maintained for 8,16 or 24 weeks. Systolic blood pressure (BP) was measured by tail-cuff plethysmography in conscious, warmed rats [21]. Glycohemoglobin (GHb) was measured by highperformance liquid chromatography (CLC330 GHb Analyzer, Primus, Kansas City, Mo., USA) [22] while glomerular filtration rate (GFR) was determined by creatinine assay [23].

\section{Diabetes Induction}

Fasting male WKY and SHR weighing between 200 and $250 \mathrm{~g}$, were randomised to receive an intravenous injection of streptozotocin (STZ) (Sigma Chemical Co., St. Louis, Mo., USA) at a dose of $50 \mathrm{mg} / \mathrm{kg}$ for WKY rats and $45 \mathrm{mg} / \mathrm{kg}$ for SHR, or sodium citrate buffer ( $\mathrm{pH} 4.5$ ) alone for control rats. Only diabetic animals with blood glucose $>15 \mathrm{mmol} / \mathrm{l}$ were included in the study. Diabetic animals were given 2-4 U of long-acting insulin (Ultralente, Novo Nordisk, Bagsvaerd, Denmark) daily to maintain body weight and to prevent ketoacidosis.

\section{Radiolabelling of Proteins}

Rat serum albumin (albumin) and rat transferrin (Sigma Chemical Co., St. Louis, Mo., USA) were carbon-14 labelled with $125 \mu \mathrm{Ci}$ $\left[{ }^{14} \mathrm{C}\right]$ formaldehyde (NEN Life Science Products, Boston, Mass., USA) using a modified reductive methylation technique [24].

Polydisperse Ficoll-70 (Sigma Chemical Co, St. Louis, Mo., USA) and dextran sulfate MW 48,000 (16\% sulfur, degree of sulfate substitution $=1.7$ sulfate groups per sugar residue) $(\mathrm{TdB}$ Consultancy, Uppsala, Sweden) were tritiated with sodium boro- $\left[{ }^{3} \mathrm{H}\right]$ hydride (NEN Life Science Products, Boston, Mass., USA) using a modified reductive methylation technique [25].

Osmotic Pump Implantation for in vivo Fractional Clearance Studies of Albumin, Transferrin and Ficoll

ALZET osmotic pumps, Model 2001 (Durect Corporation, $\mathrm{Cu}$ pertino, Calif., USA) were filled with $200 \mu 1$ of $5 \times 10^{7} \mathrm{dpm} / \mathrm{ml}$ $\left[{ }^{14} \mathrm{C}\right]$ albumin or $\left[{ }^{14} \mathrm{C}\right]$ transferrin or $200 \mu \mathrm{l}$ of $2 \times 10^{8} \mathrm{dpm} / \mathrm{ml}$ of $\left[{ }^{3} \mathrm{H}\right]$ Ficoll 70 , along with $0.002 \% \mathrm{w} / \mathrm{v}$ of thimerosal (Sigma Chemical Co., St. Louis, Mo., USA) to inhibit bacterial growth. The rats were anaesthetised by Forthane (Abbott Australasia Pty Ltd., Kurnell, Australia) inhalation and an osmotic pump was implanted subcutaneously between the scapulae using sterile technique one week before the end of each time point. The rats were placed in metabolic cages 
on days 5 and 7 after pump implantation to allow for 24-hour urine collection. Following urine collection a plasma sample was taken. Both blood and urine samples were analysed for radioactivity and by radioimmunoassay (RIA).

\section{Column Chromatography}

Polydisperse $\left[{ }^{3} \mathrm{H}\right]$ Ficoll-70 in plasma and urine samples were fractionated using an S-300 column (column dimensions $62 \mathrm{~cm} \times$ $1.6 \mathrm{~cm}^{2}$ ) (Pharmacia Fine Chemicals, Uppsala, Sweden). The column was run at $4{ }^{\circ} \mathrm{C}$ with a flow rate of $20 \mathrm{ml} / \mathrm{h}$ in PBS containing $0.2 \% \mathrm{w} / \mathrm{v}$ bovine serum albumin and $0.02 \% \mathrm{w} / \mathrm{v}$ sodium azide. Ninety-five fractions of $\sim 1.7 \mathrm{ml}$ were collected with column recoveries between 95 and $105 \% . \mathrm{K}_{\mathrm{av}}=\left(\mathrm{V}_{\mathrm{e}}-\mathrm{V}_{\mathrm{o}}\right) /\left(\mathrm{V}_{\mathrm{t}}-\mathrm{V}_{\mathrm{o}}\right)$ where $\mathrm{V}_{\mathrm{e}}$ is the elution volume, $\mathrm{V}_{\mathrm{o}}$ the void volume and $\mathrm{V}_{\mathrm{t}}$ the total volume of the column.

The $\mathrm{K}_{\mathrm{av}}$ for radiolabelled albumin, transferrin and IgG on Sephacryl S-300 was $0.464,0.424$ and 0.332 , respectively. The fractional clearance $(\mathrm{Fc})$ of $\left[{ }^{3} \mathrm{H}\right]$ Ficoll corresponding to these radii was determined by calculating the elution of $\left[{ }^{3} \mathrm{H}\right]$ Ficoll $(\mathrm{dpm} / \mathrm{ml})$ at the corresponding $\mathrm{K}_{\mathrm{av}}$, in urine and plasma samples.

\section{Lysosomal Activity}

Renal lysosomal activity was measured in vivo using the desulfation of dextran sulfate during filtration and renal passage as outlined previously [26]. Two milligrams of tritium-labelled dextran sulfate was injected intravenously into 24-week rats. A 3-hour urine sample was taken and a plasma sample. Urine samples were analysed via ion-exchange chromatography using a $19 \mathrm{~cm} \times 1 \mathrm{~cm}^{2}$ Q-Sepharose column (Pharmacia Fine Chemicals, Uppsala, Sweden). The sample was applied in $6 \mathrm{~mol} / 1$ urea, $0.05 \mathrm{~mol} / 1$ tris, $0.05 \%$ CHAPS, $0.15 \mathrm{~mol} / \mathrm{l} \mathrm{NaCl}, \mathrm{pH} 7.0$ and eluted with a linear gradient $1-2.5 \mathrm{~mol} / 1$ $\mathrm{NaCl}$ in the same buffer. The percent intact dextran sulfate was determined using the area under the curve for intact dextran sulfate compared to total dextran sulfate elution.

\section{Albumin Radioimmunoassay}

[125I]albumin was prepared using the Chloramine T method [27]. Plasma and urinary albumin concentration was measured using a double antibody RIA. The inter-assay coefficient variation was $7 \%$ at a concentration of $180 \mu \mathrm{g} / \mathrm{l}$. The detection limit of the assay was $31.2 \mu \mathrm{g} / 1$.

\section{Reverse Transcription-Polymerase Chain Reaction}

cDNA was synthesised with Superscript First Strand synthesis system for RT-PCR (Gibco BRL, Grand Island, N.Y., USA). Renal TGF- $\beta 1$ and $\beta$ ig-h 3 mRNA expression was analysed by real-time quantitative RT-PCR (TaqMan system) as previously described [28]. Primers and Taqman probe for TGF- $\beta 1, \beta$ ig-h 3 and the endogenous reference $18 \mathrm{~S}$ rRNA were constructed by Primer express (ABI Prism 7700, Perkin-Elmer Inc., Foster City, Calif., USA). TGF- $\beta 1$ (GenBank accession No.: X52498), forward primer (nucleotide 1431): 5' TTGCCCTCTACAACCAACACAA-3' and reverse primer (nucleotide 1533): 5'-GGCTTGCGACCCACGTAGTA-3'. TGF- $\beta 1$ specific probe (nucleotide 1454) was FAM-5'-CCGGGTGCTTCCGCATCACC-3'-TAMRA; FAM is 6 carboxyfluorescein, TAMRA (quencher) is 6-carboxy-tetramethylrhodamine. $\beta$ ig-h3 (GenBank accession No.: AF3057B) forward primer (nucleotide 209): 5'-TCTGCATTGAAAACAGCTGCAT- ${ }^{\prime}$ and reverse primer (nucleotide 288): 5'-CAGCATCCGGTCCATGGT-3'. $\beta$ ig-h3 specific probe (nucleotide 242) was FAM-5'-CAGGGTCCCATACCGTCCCTTCTTG-
T-3'-TAMRA. Results expressed relative to control kidneys, which were arbitrarily assigned a value of 1 .

\section{Counting of Radioactivity}

Tritium and carbon-14 radioactivity was determined using a 1:3 ratio of sample to Optiphase scintillation fluid and recorded on a Wallac 1409 liquid scintillation counter (Wallac, Finland).

\section{Statistics}

Data are expressed as mean \pm SE where $n$ represents the number of determinations. Normally distributed variables in different groups were compared by analysis of variance using the Statview program (Brain Power, Calabasas, Calif., USA). Comparisons between group means were performed by Fisher's least significant difference method. $p<0.05$ was considered statistically significant.

\section{Equations}

Fc was determined using the equation:

$\mathrm{Fc}=([$ urinary albumin $] /[$ plasma albumin $]) \times(\mathrm{UFR} / \mathrm{GFR})$,

where UFR is the urine flow rate $(\mathrm{ml} / \mathrm{min})$.

Total albumin (intact plus albumin-derived peptides) excretion was calculated as

([plasma albumin $(\mathrm{mg} / \mathrm{ml})] /[$ plasma albumin $(\mathrm{dpm} / \mathrm{ml})])$

$\times$ [urine total albumin (intact plus peptides) $(\mathrm{dpm} / \mathrm{ml})$ ]

$\times$ [urine volume $(\mathrm{ml} / 24 \mathrm{~h})$,

where plasma albumin $(\mathrm{mg} / \mathrm{ml})$ is determined by RIA.

Percent intact albumin was determined as

RIA intact albumin $(\mathrm{mg} / 24 \mathrm{~h}) /$ total albumin $(\mathrm{mg} / 24 \mathrm{~h}) \times 100$.

\section{Results}

\section{Physiological Parameters}

The results in table 1 demonstrate that diabetic rats exhibited significantly elevated GHb levels (table 1$)(\mathrm{p}<$ 0.001 ). This trend was also followed for kidney to body weight ratio and urine volume which both increased as a result of diabetes (table 1$)(p<0.001)$. Body weight was lower in diabetic versus control groups (table 1$)$ ( $p<$ 0.001 ) at 8,16 and 24 weeks. Plasma albumin decreased for diabetic rats 16 weeks and older. The GFR at 24 weeks was WKY-c $2.52 \pm 0.19 \mathrm{ml} / \mathrm{min}$, SHR-c $2.89 \pm 0.20 \mathrm{ml} /$ $\mathrm{min}, \mathrm{WKY}-\mathrm{d} 2.16 \pm 0.09 \mathrm{ml} / \mathrm{min}(\mathrm{p}<0.01$ vs. SHR-c) and SHR-d $1.84 \pm 0.10 \mathrm{ml} / \mathrm{min}(\mathrm{p}<0.001$ versus SHR-c and $\mathrm{p}<0.01$ vs. WKY-c).

\section{Blood Pressure}

Systolic blood pressure was significantly higher in the SHR groups at all time points in comparison to the normotensive WKY groups (fig. 1) $(\mathrm{p}<0.001)$. 


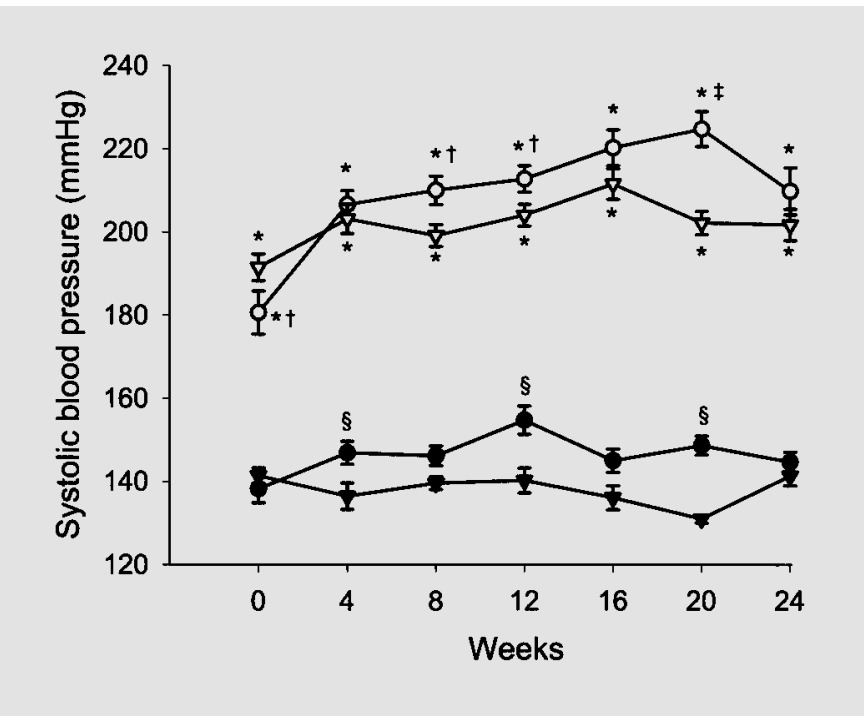

Fig. 1. Systolic blood pressure over time. Closed circles $=\mathrm{WKY}-\mathrm{c}$; open circles $=$ SHR-c; closed triangle $=\mathrm{WKY}-\mathrm{d} ;$ open triangle $=$ SHR-d. ${ }^{*} \mathrm{p}<0.001$ SHR versus WKY groups. ${ }^{\dagger} \mathrm{p}<0.05,{ }^{\star} \mathrm{p}<0.001$ versus SHR-d. ${ }^{\#} \mathrm{p}<0.05$ versus WKY-d. Data pooled at each time point $\mathrm{n}=6-30$. Data presented as mean \pm SEM.

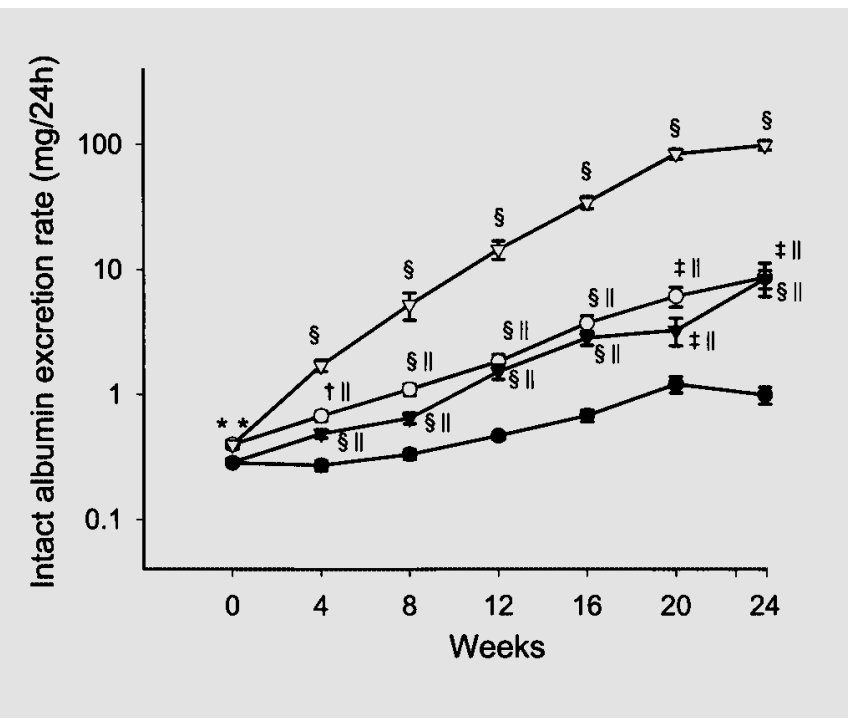

Fig. 2. Intact albumin excretion over time. Closed circles = WKY-c; open circles $=$ SHR-c; closed triangle $=\mathrm{WKY}$-d; open triangle $=$ SHR-d. ${ }^{*} \mathrm{p}<0.001$ versus WKY groups. ${ }^{\dagger} \mathrm{p}<0.05,{ }^{*} \mathrm{p}<0.01,{ }^{\S} \mathrm{p}<$ 0.001 versus WKY-c. $\| \mathrm{p}<0.001$ versus SHR-d. Data pooled at each time point $n=6-30$. Data presented as mean \pm SEM.

Table 1. Physiological parameters

\begin{tabular}{lclllll}
\hline Group & Week & $\begin{array}{l}\text { GHb } \\
\%\end{array}$ & $\begin{array}{l}\text { Kidney/body } \\
\text { weight ratio } \\
\left(10^{-5}\right), \mathrm{mg} / \mathrm{g}\end{array}$ & $\begin{array}{l}\text { Body weight } \\
\mathrm{g}\end{array}$ & $\begin{array}{l}\text { UFR } \\
\mathrm{ml} / 24 \mathrm{~h}\end{array}$ & $\begin{array}{l}\text { Plasma } \\
\text { albumin } \\
\mathrm{mg} / \mathrm{ml}\end{array}$ \\
\hline WKY-c & 8 & $2.75 \pm 0.06$ & $322 \pm 5$ & $361 \pm 4$ & $11 \pm 1$ & $30.6 \pm 0.8$ \\
& 16 & $3.05 \pm 0.08$ & $311 \pm 5$ & $419 \pm 5$ & $12 \pm 1$ & $35.4 \pm 1.1$ \\
& 24 & $3.64 \pm 0.24$ & $302 \pm 3$ & $427 \pm 5$ & $10 \pm 1$ & $29.7 \pm 0.7$ \\
SHR-c & 8 & $3.03 \pm 0.08$ & $315 \pm 9$ & $387 \pm 7$ & $14 \pm 0.5$ & $31.0 \pm 1.7$ \\
& 16 & $3.35 \pm 0.09$ & $307 \pm 2$ & $449 \pm 12^{* * *}$ & $16 \pm 1$ & $33.8 \pm 1.0$ \\
WKY-d & 24 & $3.64 \pm 0.17$ & $314 \pm 7$ & $468 \pm 14^{* * *}$ & $16 \pm 1$ & $28.2 \pm 1.0$ \\
& 16 & $12.47 \pm 0.42^{*}$ & $539 \pm 16^{*} * *$ & $300 \pm 7^{*}, * *$ & $85 \pm 9^{*}$ & $29.5 \pm 0.7$ \\
& 24 & $11.82 \pm 0.49^{*}$ & $473 \pm 10^{*}$ & $333 \pm 9^{*}$ & $97 \pm 6^{*}$ & $25.0 \pm 0.8^{* *, * * *}$ \\
SHR-d & 8 & $12.07 \pm 0.55^{*}$ & $479 \pm 15^{*}$ & $324 \pm 14^{*}$ & $71 \pm 6^{*}$ & $26.2 \pm 0.7^{\#}$ \\
& 16 & $11.55 \pm 0.30^{*}$ & $498 \pm 9^{*}$ & $266 \pm 5^{*}$ & $98 \pm 3^{*}$ & $27.8 \pm 0.4^{*}$ \\
& 24 & $12.09 \pm 0.52^{*}$ & $482 \pm 9^{*}$ & $316 \pm 6^{*}$ & $110 \pm 9^{*}$ & $26.0 \pm 0.7^{* *, * * *}$ \\
& $11.82 \pm 0.39^{*}$ & $457 \pm 3^{*}$ & $336 \pm 9^{*}$ & $65 \pm 4^{*}$ & $26.1 \pm 0.9^{\#}$ \\
\hline
\end{tabular}

Data shown as mean \pm SEM. GHb 8, 16 and 24 weeks $* \mathrm{p}<0.001$. Body/kidney weight ratio 8,16 and 24 weeks $* \mathrm{p}<0.001$ control versus diabetic groups, 8 weeks $* * \mathrm{p}<0.05$ versus SHR-d. Body weight 8,16 and 24 weeks * $\mathrm{p}<$ 0.001 control versus diabetic groups, 8 weeks $* * \mathrm{p}<0.001$ versus SHR-d, 16 and 24 weeks $* * * \mathrm{p}<0.05$ versus WKY-c. Urine flow rate 8,16 and 24 weeks $* \mathrm{p}<0.001$ control versus diabetic. Plasma albumin 8 weeks $* \mathrm{p}<0.05$ versus SHR-c, 16 weeks $* * \mathrm{p}<0.001$ versus SHR-c, ${ }^{* * *} \mathrm{p}<0.001$ versus WKY-c, 24 weeks ${ }^{\#} \mathrm{p}<0.01$ versus WKY-c. $\mathrm{n}=$ $6-20$. 
Fig. 3. a Fractional clearance $\left[{ }^{3} \mathrm{H}\right]$ Ficoll at 24 weeks. Open bars = WKY-c, forward slash bars $=$ SHR-c, back slash bars $=$ WKY$\mathrm{d}$, hatched bars $=$ SHR-d. ${ }^{*} \mathrm{p}<0.05$ versus WKY-d. $n=4-6$. Data presented as mean \pm SEM. b Fractional clearance of intact albumin by RIA, $\left[{ }^{14} \mathrm{C}\right]$ albumin, intact transferrin by RIA and $\left[{ }^{14} \mathrm{C}\right]$ transferrin at 24 weeks. Open bars $=$ WKY-c, forward slash bars = SHR-c, back slash bars $=$ WKY-d, hatched bars $=$ SHR-d. Fc RIA albumin $*$ p $<0.01$, ${ }^{\dagger} \mathrm{p}<0.001$ versus WKY-c, ${ }^{\star} \mathrm{p}<0.001$ versus SHR-d. Fc $\left[{ }^{14} \mathrm{C}\right]$ albumin ${ }^{\S} \mathrm{p}<0.001$ versus SHR-d, $\|$ p $<0.005$ versus WKY-d. Fc RIA transferrin ${ }^{\mathrm{T}} \mathrm{p}<0.001$ versus all other groups, ${ }^{*} \mathrm{p}<0.05$ versus WKY-c. Fc $\left[{ }^{14} \mathrm{C}\right]$ transferrin ${ }^{* *} \mathrm{p}<0.01$ versus WKY-c. $\mathrm{n}=6-16$. Data presented as mean \pm SEM.
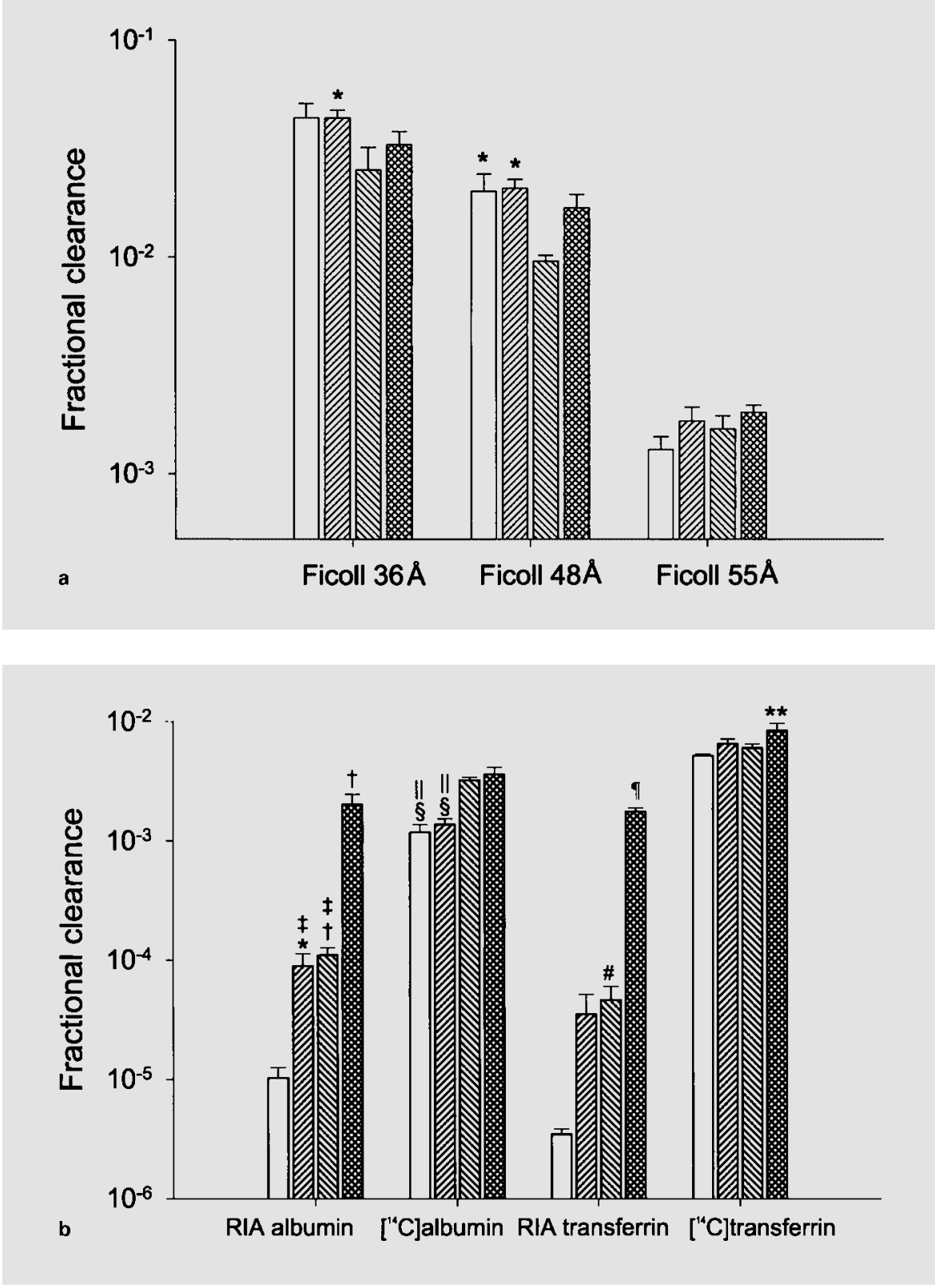

\section{Intact Albumin Excretion Rate}

Intact albumin excretion as determined by RIA (fig. 2) was significantly higher in the SHR versus WKY groups at 0 weeks. Both the WKY-d and SHR-c groups exhibited a progressive increase in intact albumin excretion over the 24 weeks with an approximate 10-fold increase at 24 weeks compared to WKY-c. Combined hypertension and diabetes (SHR-d) showed a more rapid and significant increase in intact albumin excretion which resulted in a 100-fold increase over the 24-week period.

\section{Glomerular Permeability}

To determine the origins of the increase in intact albumin excretion, glomerular permeability was determined using Ficoll which has a globular structure like albumin and is not reabsorbed by the tubules [29, 30]. Figure 3a demonstrates that there was no significant increase in glomerular permeability to molecules of radii 36,48 or $55 \AA$ at 24 weeks in all groups studied. There was, however, a lower Ficoll Fc at 36 and $48 \AA$ in WKY-d versus SHR-c $(p<0.05)$. These results also show that the Fc of Ficoll is 

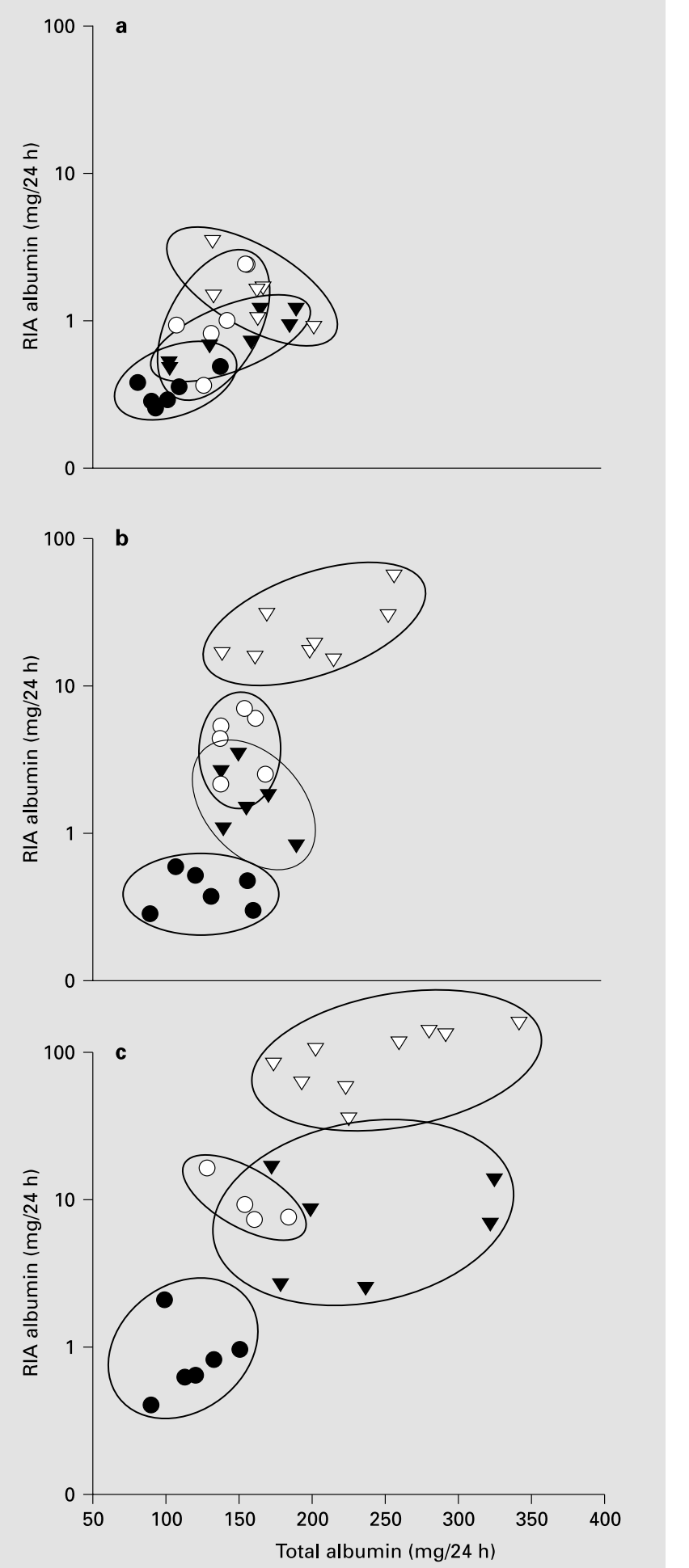

Fig. 4. a-c Comparison of total and intact albumin excretion for each rat studied at 8 (a), 16 (b) and 24 (c) weeks. Closed circles $=$ WKY-c; open circles = SHR-c; closed triangle $=$ WKY-d; open triangle $=$ SHR-d. Data was obtained from day 7 osmotic pump studies. significantly greater than the Fc of radiolabelled proteins of similar hydrodynamic radius such as albumin $(36 \AA)$ and transferrin ( $48 \AA$ ) (fig. $3 b$ ) as these proteins are reabsorbed by the tubules.

\section{Protein Fractional Clearance Studies}

The Fcs of albumin and transferrin were determined using both radiolabelled proteins and RIA (fig. 3b). The Fc of intact proteins, as measured by RIA, was relatively lower than that of ${ }^{14} \mathrm{C}$-labelled protein (total albumin or total transferrin) as intact protein represents a relatively small proportion of the total amount of protein excreted. The Fc of the intact albumin increased approximately 10fold in the SHR-c and WKY-d groups. The intact albumin Fc increased most significantly in the SHR-d group $(\mathrm{p}<$ 0.001 ) versus all groups (fig. $3 \mathrm{~b}$ ). The relative increase in total albumin $\mathrm{Fc}$ was only significant in the diabetic groups, despite significant increases in intact albumin excretion being observed in all groups. The $\mathrm{Fc}$ of $\left[{ }^{14} \mathrm{C}\right]$ transferrin (total transferrin) also increased significantly in the SHR-d versus WKY-c groups $(p<0.05)$ (fig. 3b). The changes in intact transferrin excretion followed the same trend as intact albumin excretion suggesting a common underlying mechanism in the processing of these proteins and its disruption in diabetes and/or hypertension.

\section{Intact versus Total Albumin Excretion}

Analysis of the relationship between intact and total albumin excretion at 8,16 and 24 weeks (fig. $4 a$, b and c, respectively) revealed a number of distinct features. For the control group, the amount of intact albumin was less than $1 \%$ of the total albumin due to the large quantity of albumin fragments in the urine. Within the WKY-c group, the variation of total albumin excretion was large, ranging from 90 to $160 \mathrm{mg} / 24 \mathrm{~h}$. This variation is primarily due to the variation in the relatively high level of albumin fragment excretion or peptiduria that has previously been unreported. The major change associated with the SHR-c group was essentially a progressive increase in intact albumin (fig. $4 a-c)$ without any significant change in total albumin excretion. Both groups of diabetic rats exhibited markedly different behaviour and followed a trend of an early increase in intact albumin excretion followed by a later increase in total albumin excretion. The WKY-d group showed moderate increases in intact albumin excretion much the same as the SHR-c, but a much larger range of total albumin excretion where the mean was significantly higher than the control (WKY-c $117 \pm 9 \mathrm{mg} / 24 \mathrm{~h}$, WKY-d $239 \pm 28 \mathrm{mg} / 24 \mathrm{~h}$, SHR-c $158 \pm 9 \mathrm{mg} / 24 \mathrm{~h}$, 
Fig. 5. Percentage intact urinary excretion of $\left[{ }^{3} \mathrm{H}\right]$ dextran sulfate and $\left[{ }^{14} \mathrm{C}\right]$ albumin at 24 weeks. Closed bars $=\left[{ }^{3} \mathrm{H}\right]$ dextran sulfate, open bars $=\left[{ }^{14} \mathrm{C}\right]$ albumin. $\%$ intact $\left[{ }^{3} \mathrm{H}\right] \mathrm{dex}-$ tran sulfate $* \mathrm{p}<0.05,{ }^{\dagger} \mathrm{p}<0.001$ versus WKY-c. $* \mathrm{p}<0.001$ versus SHR-d. \% intact albumin $\S \mathrm{p}<0.001$ versus all other groups. $\mathrm{n}=4-6$.

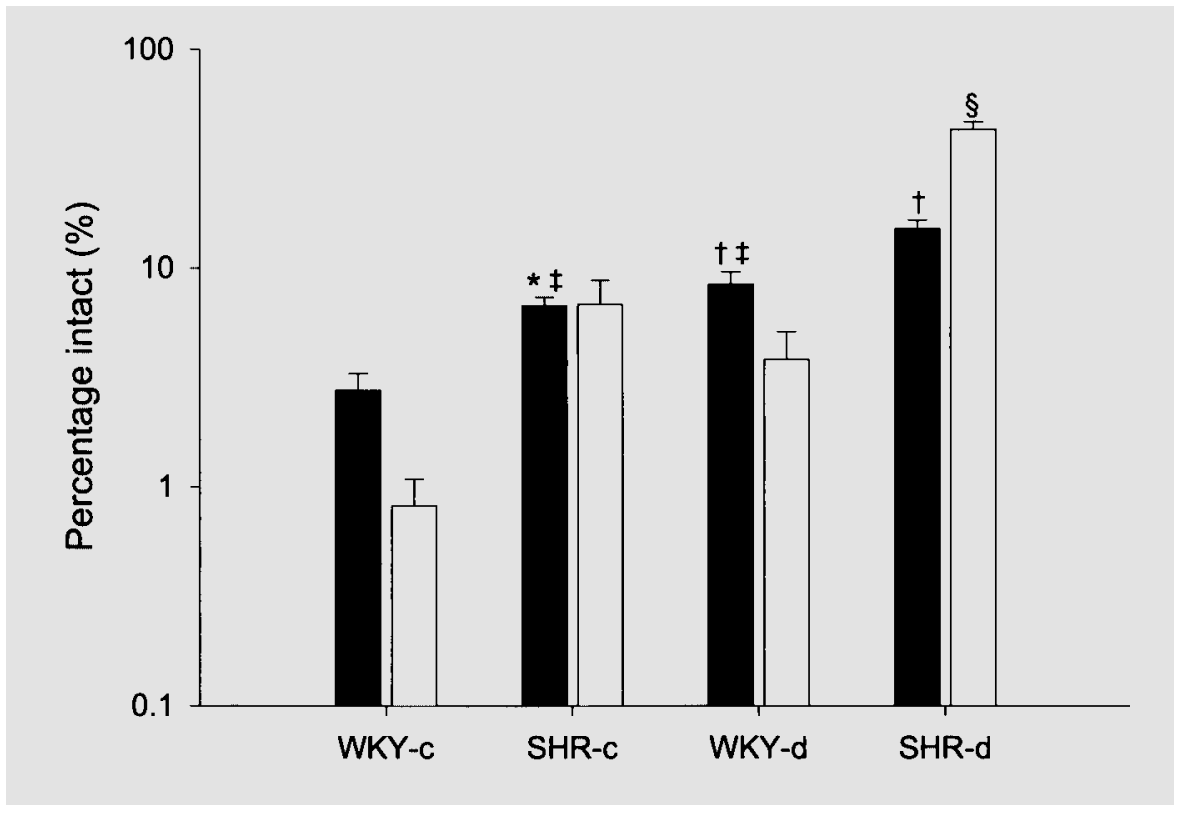

SHR-d $243 \pm 18 \mathrm{mg} / 24 \mathrm{~h} \mathrm{p}<0.05$ diabetic versus control groups). Similar changes in total albumin excretion were observed for the SHR-d group, however with a relatively greater increase in intact albumin excretion.

\section{Lysosomal Activity}

The results in figure $4 \mathrm{a}-\mathrm{c}$ demonstrate that the changes in the degradation of filtered albumin, without change in total albumin excretion, are responsible for the initial increases in intact albumin excretion. Thus analysis of lysosomal activity amongst the groups was determined (fig. 5). The desulfation of dextran sulfate is affected by lysosomal sulfatases and their activity may be considered as a marker of in vivo renal lysosomal activity. In 24-week rats, the amount of intact urinary dextran sulfate increases in all groups exhibiting increases in intact albuminuria. This increase was highest in the SHR-d group ( $p$ $<0.001$ ) versus WKY-c.

\section{TGF- $\beta$ and $\beta i g-h 3$ mRNA Expression}

Figure $6 \mathrm{a}$ shows a trend of increased renal TGF- $\beta 1$ mRNA in albuminuric groups. Increased translation of TGF- $\beta 1$ was confirmed by increased $\beta$ ig-h3 mRNA (fig. 6b) (expression of which is induced by increased TGF- $\beta 1$ production) [20]. $\beta$ ig-h3 mRNA shows a general increase over time with a significant increase at 24 weeks in all groups with albuminuria in parallel with decreased lysosomal activity and increased intact albumin excretion at 24 weeks (fig. 5).

Albumin Excretion in Diabetes and Hypertension

\section{Discussion}

A widely cited mechanism of albuminuria associated with diabetes is that caused by alterations in glomerular permeability including loss of charge selectivity and formation of large pores [31-36]. Increases in glomerular permeability associated with hyperfiltration in hypertension has also been thought to account for albuminuria in hypertension [37-39]. The present studies have demonstrated that it is unlikely that alterations to transglomerular capillary wall transport could account for the observed changes in albuminuria and peptiduria. We have demonstrated in this study that changes in the permeability of the GCW were not apparent when Ficoll Fc was measured. There was no formation of large pores. In addition, we have previously established that glomerular charge selectivity is not a factor as studies have demonstrated this to be negligible $[10,40]$. While there were significant increases in systemic blood pressure in the SHRs there was no corresponding increase in GFR thus eliminating the possibility of glomerular hyperfiltration of albumin. These results show that glomerular permeability to albumin is unaltered in diabetic and hypertensive states in rats.

Previously, TGF- $\beta$ has been implicated in the early events associated with diabetic nephropathy, particularly with increased glucose levels $[11,12]$ and its effect on lysosomal activity [19]. Our studies demonstrate a correlation between elevated levels of renal TGF- $\beta 1$ and changes in renal lysosomal activity as measured by the 
Fig. 6. a Real time reverse transcription PCR for renal TGF- $\beta 1$ mRNA at 8,16 and 24 weeks. Open bars $=$ WKY-c, forward slash bars $=$ SHR-c, back slash bars $=$ WKY $\mathrm{d}$, hatched bars $=$ SHR-d. ${ }^{*} \mathrm{p}<0.05$ versus WKY-c. $n=4-5$ for each group. Data presented as mean \pm SEM. b Real time reverse transcription PCR for $\beta$ ig-h3 mRNA expression at 8, 16 and 24 weeks. Open bars = WKY-c, forward slash bars = SHR-c, back slash bars $=$ WKY-d, hatched bars $=$ SHR-d. ${ }^{\dagger} \mathrm{p}<0.05$ versus SHR-c. $* \mathrm{p}<0.05$ versus WKY-c. $\mathrm{n}=4-5$ for each group at each time point. Data presented as mean $\pm \mathrm{SEM}$.
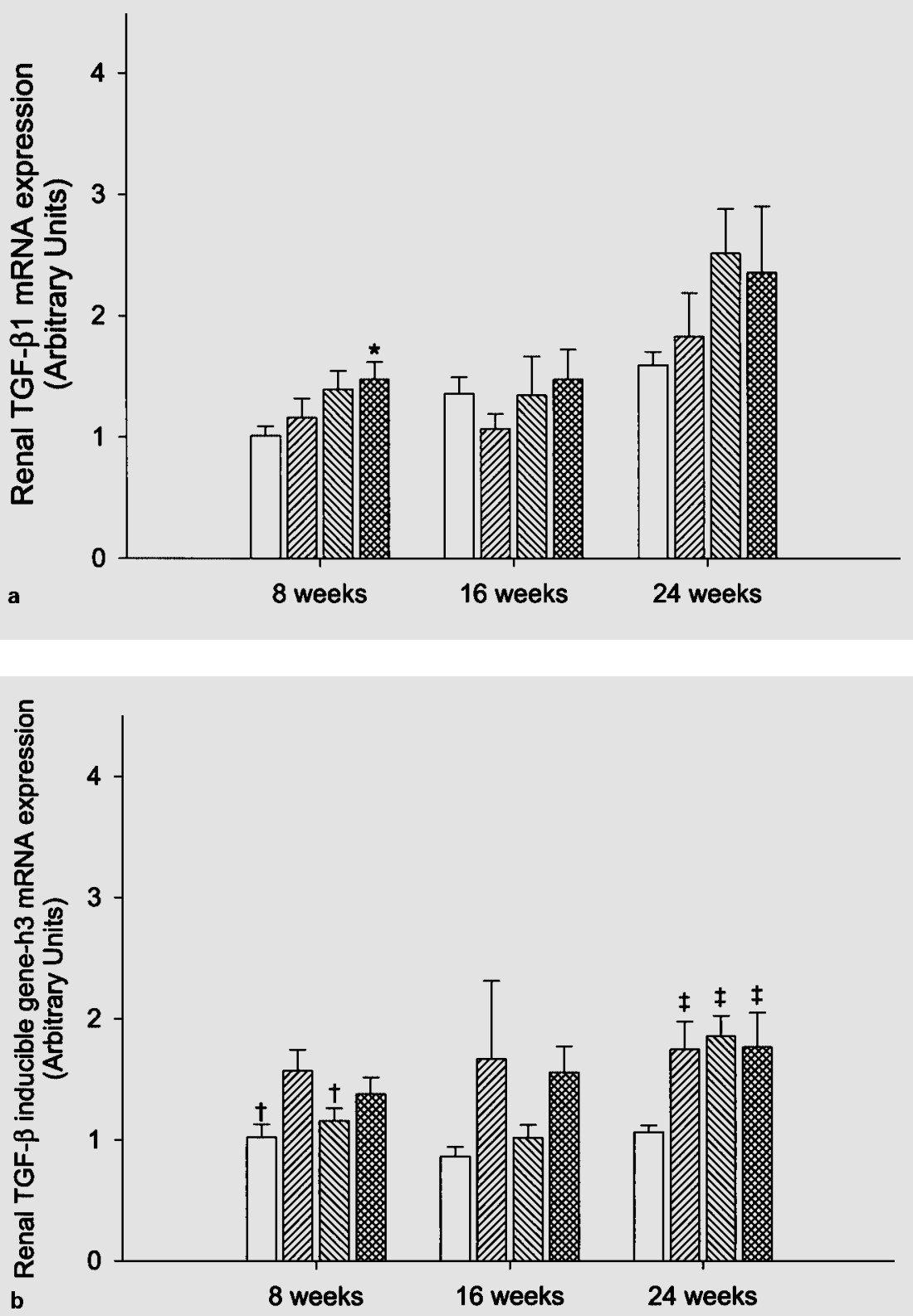

degree of degradation of excreted albumin and dextran sulfate. These findings would concur with recent studies by Adler et al. [41] that demonstrate that intact albuminuria in diabetic nephropathy is correlated with increases in glomerular mRNA for connective tissue growth factor that is produced after cellular stimulation with TGF- $\beta$.

The onset of albuminuria by changes in lysosomal activity may account for the albuminuria seen in hypertension. It also appears to be amplified in hypertensivediabetic rats. Its occurrence is correlated with increases in
TGF- $\beta$ and decreases in renal lysosomal activity. In diabetes, there appears to be an additional mechanism operating involving peptiduria. Peptiduria increased in both diabetic and diabetic-hypertensive rats. There was effectively no increase in peptiduria in hypertension alone. It was also apparent that the time dependent onset of intact albuminuria and peptiduria was different. Intact albuminuria occurs early in the progression of the disease whereas the development of peptiduria appears to have a later onset in diabetic states. 
The peptiduria is unusual in the context that we have identified that lysosomal activity is reduced yet peptide excretion (resulting from lysosomal activity) is enhanced. We rationalise peptiduria as resulting from a malfunction of the high capacity retrieval pathway for albumin [6]. Albumin not retrieved by this pathway has the opportunity to be taken up by the degradation pathway downstream from the retrieval pathway. This albumin is then degraded prior to excretion. While the amount of albumin being exposed to the degradation pathway is greater in diabetes, paradoxically there is a simultaneous inhibition of lysosomal activity as more albumin escapes degradation and is excreted intact. Increases in the capacity of the degradation pathway may be inherent within normal and diabetic kidneys such that saturation has not been achieved or there may be increased turnover or trafficking of albumin to the lysosome. It is apparent that when the analysis of albumin is confined to intact albumin alone as in previous studies, then conclusions concerning renal handling of albumin will be incomplete as peptiduria will not have been taken into account.

Very high levels of peptides have previously been identified in the urines of normo- and micro-albuminuric diabetic patients [42].The enhanced excretion of peptides in diabetic nephropathy was suggested from the semi-quantitative studies on micro- and macro-albuminuric diabetic patients [8]. This study quantitatively demonstrates that the major increase in proteinaceous material in urine in experimental diabetes is due to finite increases in peptiduria. This appears to be a unique feature of albuminuric states in diabetes.

In diabetic rats, the level of albumin derived material in urine is approaching nephrotic states comparable to that obtained in anti-glomerular basement membrane glomerulonephritis (anti-GBM GN) and puromycin aminonucleoside nephritis (PAN) [10]. There are, however, major differences with classic nephrosis in terms of (1) while there is a significant decrease in plasma albumin for dia- betic and diabetic-hypertensive rats it does not compare to the $>60 \%$ decrease observed in PAN and anti GBM GN [10]; (2) that the excreted protein is in the form of protein fragments as compared to the intact protein found in nephritis, and (3) the Fc of albumin is still considerably lower than the Fc of albumin measured for anti GBM GN and PAN. High levels of glomerular albumin permeability have been reported in studies of swollen isolated glomeruli obtained from STZ diabetic rats [43, 44]. While these results clearly reflect structural alterations in these glomeruli, it remains to be determined what quantitative relationship these in vitro permeability measurements have in relation to in vivo states.

To our knowledge this is the first time albuminuria in hypertension and diabetes has been analysed in terms of the permutations of two different mechanisms of post GBM albumin processing that are clearly independent of glomerular permeability. This study also provides evidence that increased renal TGF- $\beta 1$ may be linked to increased intact albumin excretion in diabetes, hypertension and possibly in the early stages of the combined state. These results may be pertinent in explaining the observations made in the early stages of diabetic nephropathy where defects in the tubular handling of filtered proteins have been proposed [45]. Finally, this paper identifies peptiduria as an important component of albuminuria in diabetes, the monitoring of which may give new clues as to the diagnosis of the onset and progression of diabetic nephropathy and the design of improved anti-albuminuric/proteinuric drugs.

\section{Acknowledgements}

This work was supported by a grant from Diabetes Australia. Dr. Tanya Osicka was a recipient of a Juvenile Diabetes Research Foundation Postdoctoral Fellowship. We gratefully acknowledge the excellent technical assistance of Brenda Baldacchino, Steven Sastra and Cleo Christodoulou.

\section{References}

1 Viberti GF: Prognostic significance of albuminuria for the development of nephropathy. $\mathrm{J}$ Hypertens 1995;13:S87-S89.

2 Rosa TT, Palatini P: Clinical value of microalbuminuria in hypertension. J Hypertens 2000; 18:645-654

3 Osicka TM, Pratt LM, Comper WD: Glomerular capillary wall permeability to albumin and horseradish peroxidase. Nephrol 1996;2:199_ 212 .
4 Osicka TM, Panagiotopoulos S, Jerums G Comper WD: Fractional clearance of albumin is influenced by albumin degradation. Clin Sci 1997;93:557-564.

5 Burne MJ, Panagiotopoulos S, Jerums G, Comper WD: Alterations in renal degradation of albumin in early experimental diabetes in the rat: A new factor in the mechanism of albuminuria. Clin Sci 1998;95:67-72.
6 Eppel GA, Osicka TM, Pratt LM, Jablonski P, Howden B, Glasgow EF, Comper WD: The return of glomerular filtered albumin to the rat renal vein. Kidney Int 1999;55:1861-1870.

7 Osicka TM, Comper WD: Protein degradation during renal passage in normal kidneys is inhibited in experimental albuminuria. Clin Sci 1997;93:65-72. 
8 Osicka TM, Houlihan CA, Chan JG, Jerums G, Comper WD: Albuminuria in patients with type 1 diabetes is directly linked to changes in the lysosomal-mediated degradation of albumin during renal passage. Diabetes 2000;49: 1579-1584.

9 Burne MJ, Osicka TM, Comper WD: Fractional clearance of high molecular weight proteins in conscious rats using a continuous infusion method. Kidney Int 1999;55:261-270.

10 Greive KA, Nikolic-Paterson DJ, Nikolovski J, Pratt LM, Mu W, Atkins RC, Comper WD: Glomerular permselectivity factors are not responsible for the increase in fractional clearance of albumin in rat glomerulonephritis. Am J Pathol 2001;159:1159-1170.

11 Hill C, Flyvbjerg A, Grønbæk H, Petrik J, Hill DJ, Thomas CR, Sheppard MC, Logan A: The renal expression of transforming growth factor$\beta$ isoforms and their receptors in acute and chronic experimental diabetes in rats. Endocrinology 2000;141:1196-1208.

12 Ziyadeh FN, Sharma K, Ericksen M, Wolf G: Stimulation of collagen gene expression and protein synthesis in murine mesangial cells by high glucose is mediated by autocrine activation of transforming growth factor- $\beta$. J Clin Invest 1994;93:536-542.

13 Hamaguchi A, Kim S, Ohta K, Yagi K, Yukimura T, Miura K, Fukuda T, Iwao H: Transforming growth factor-beta 1 expression and phenotypic modulation in the kidney of hypertensive rats. Hypertension 1995;26:199-207.

14 Riser BL, Cortes P, Heilig C, Grondin J, Ladson-Wofford S, Patterson D, Narins RG: $\mathrm{Cy}-$ clic stretching force selectively upregulates TGF-beta isoforms in cultured rat mesangial cells. Am J Pathol 1996;148:1915-1923.

15 Hirakata M, Kaname S, Chung UG, Joki N, Hori Y, Noda M, Takuwa Y, Okazaki T, Fujita $\mathrm{T}$, Katoh T, Kurokawa K: Tyrosine kinase dependent expression of TGF-beta induced by stretch in mesangial cells. Kidney Int 1997;51: 1028-1036.

16 Li Q, Muragaki Y, Hatamura I, Ueno H, Ooshima A: Stretch-induced collagen synthesis in cultured smooth muscle cells from rabbit aortic media and a possible involvement of angiotensin II and TGF-beta. J Vasc Res 1998;35:93103.

17 Nakamura T, Miller D, Rouslahti E, Border WA: Production of extracellular matrix by glomerular epithelial cells is regulated by transforming growth factor $\beta 1$. Kidney Int 1992; 41 : 1213-1221.

18 Roberts AB, McCune BK, Sporn MB: TGF- $\beta 1$ : Regulation of extracellular matrix. Kidney Int 1992;41:557-559.

19 Schenk O, Ling H, Sebekova K, Vamvakas S, Heidland A: High-glucose media enhance the responsiveness of tubular cells to growth promoters: Effect on lysosomal cathepsins and protein degradation. Miner Electrolyte Metab 1998;24:254-260.
20 Gilbert RE, Wilkinson-Berka JL, Johnson DW, Cox A, Soulis T, Wu LL, Kelly DJ, Jerums G, Pollock CA, Cooper ME: Renal expression of transforming growth factor- $\beta$ inducible geneh3 ( $\beta$ ig-h3) in normal and diabetic rats. Kidney Int 1998;54:1052-1062.

21 Bunag RD: Validation in awake rats of a tailcuff method for measuring systolic blood pressure. J Appl Physiol 1973;34:279-282.

22 Cefalu WT, Wang ZQ, Bell-Fallow A, Kiger FD, Izlar C: Glycohemoglobin measured by automated affinity HPLC correlates with both short-term and long-term antecedent glycemia. Clin Chem 1994;40:1317-1321.

23 Di Giorgio J: Non protein nitrogenous constituents; in Henry R, Canon D, Winkelman J (eds): Clinical Chemistry: Principles and Techniques. Hagerstown, Harper \& Row, 1974, pp 503-563.

24 Eng LA: Production and characterization of $\left[{ }^{14} \mathrm{C}\right]$ protein $\mathrm{A}$, a long lived immunological reagent. J Immunol Methods 1985;81:239-243.

25 Tack BF, Dean J, Eilat D, Lorenz PE, Schecter AN: Tritium labelling of proteins to high specific radioactivity by reductive methylation. $\mathrm{J}$ Biol Chem 1980;255:8842-8847.

26 Osicka TM, Kiriazis Z, Pratt LM, Jerums G, Comper WD: Ramipril and aminoguanidine restore renal lysosomal processing in streptozotocin diabetic rats. Diabetologia 2001;44:230236.

27 Greenwood FC, Hunter WM, Glover JS: The preparation of ${ }^{131}$ I-labelled human growth hormone of high specific radioactivity. Biochem $\mathrm{J}$ 1963;89:114-123.

28 Bonnet F, Cooper ME, Kawachi H, Allen TJ, Boner G, Cao Z: Irbesartan normalises the deficiency in glomerular nephrin expression in a model of diabetes and hypertension. Diabetologia 2001;44:874-877.

29 Bohrer MP, Deen WM, Robertson CR, Troy JL, Brenner BM: Influence of molecular configuration on the passage of macromolecules across the glomerular capillary wall. J Gen Physiol 1979;74:583-593.

30 Oliver JD, Anderson S, Troy JL, Brenner BM, Deen WM: Determination of glomerular size selectivity in the normal rat with ficoll. J Am Soc Nephrol 1992;3:214-228.

31 Myers BD, Winetz JA, Chui F, Michaels AS: Mechanisms of proteinuria in diabetic nephopathy: A study of glomerular barrier function. Kidney Int 1982;21:633-641.

32 Deckert T, Kofoed-Enevoldsen A, Vidal P, Nørgaard K, Andreasen HB, Feldt-Rasmussen B: Size and charge selectivity of glomerular filtration in type I (insulin-dependent) diabetic patients with and without albuminuria. Diabetologia 1993;36:244-251.
33 Gall M-A, Rossing P, Kofoed-Enevoldsen A, Nielsen FS, Parving H-H: Glomerular size and charge selectivity in type 2 (non insulin-dependent) diabetic patients with diabetic nephropathy. Diabetologia 1994;37:195-201.

34 Fox JG, Quin JD, Paterson KR, O'Reilly DSTJ, Smith MP, Boulton-Jones JM: Glomerular charge selectivity in type I (insulin-dependent) diabetes mellitus. Diabetic Med 1995;12: 387-391.

35 Ruggenenti P, Mosconi L, Sangalli F, Casaraghi F, Gambara V, Remuzzi G, Remuzzi A: Glomerular size-selectivity dysfunction in NIDDM is not ameliorated by ACE inhibition or by calcium channel blockade. Kidney Int 1999;55:984-994.

36 Andersen S, Blouch K, Bialek J, Deckert M, Parving H-H, Myers BD: Glomerular permselectivity in early stages of overt diabetic nephropathy. Kidney Int 2000;58:2129-2137.

37 Brenner BM: Hemodynamically mediated glomerular injury and the progressive nature of kidney disease. Kidney Int 1983;23:647-655.

38 Hostetter TH: Diabetic nephropathy. N Eng J Med 1985;312:642-644.

39 Simons JL, Provoost AP, Anderson S, Rennke HG, Troy JL, Brenner BM: Modulation of glomerular hypertension defines susceptibility to progressive glomerular injury. Kidney Int 1996;46:396-404.

40 Russo LM, Bakris GL, Comper WD: Renal handling of albumin: A critical review of basic concepts and perspective. Am J Kidney Dis 2002;39:899-919.

41 Adler SG, Kang S-W, Feld S, Cha DR, Barba L, Striker L, Striker G, Riser BL, LaPage J, Nast CC: Glomerular mRNAs in human type 1 diabetes: Biochemical evidence for microalbuminuria as a manifestation of diabetic nephropathy. Kidney Int 2001;60:2330-2336.

42 Greive KA, Balazs NDH, Comper WD: Protein fragments in urine have been considerably underestimated by various protein assays. Clin Chem 2001;47:1717-1719.

43 Carraro M, Mancini W, Artero M, Zennaro C, Faccini L, Candido R, Armini L, Calci M, Carretta R, Fabris B: Albumin permeability in isolated glomeruli in incipient experimental diabetes mellitus. Diabetologia 2000;43:235-241.

44 Fabris B, Candido R, Carraro M, Fior F, Artero M, Zennaro C, Cattin MR, Fiorotto A, Bortoletto M, Millevoi C, Bardelli M, Faccini L, Carretta R: Modulation of incipient glomerular lesions in experimental diabetic nephropathy by hypertensive and subhypertensive dosages of an ACE inhibitor. Diabetes 2001;50:26192624.

45 Lemley KV, Blouch K Abdullah I, Boothroyd DB, Bennett PH, Myers BD, Nelson RG: Glomerular permselectivity at the onset of nephropathy in type 2 diabetes mellitus. $\mathbf{J}$ Am Soc Nephrol 2000;11:2095-2105. 